\title{
Is there a relationship between the lengths of the ipsilateral clavicle and the ulna? An anthropometric and statistical study
}

\author{
Klavikula ve ulna boyları arasında anlamlı bir oran varmı? Antropometrik ve \\ istatistiksel bir çalıșma
}

\author{
Mehmet Salih Söylemez $^{1}$, Murat Demiroğlu ${ }^{2}$, Davut Aydın ${ }^{2}$, Fuat Akpınar ${ }^{2}$, Bülent Kılıç ${ }^{3}$, Ömer K. Ünal ${ }^{2}$, \\ Korhan Özkan ${ }^{2}$
}

\begin{abstract}
Aim: Mathematical relationships between bones in close proximity are useful for determining the proper length of comminuted or severely displaced bones during surgical reconstruction. This study examined the relationship between the lengths of the clavicle and ulna to develop a length propotion formula that can facilitate obtaining the proper length of the clavicle during surgery for displaced and comminuted fractures.

Methods: The study enrolled 130 individuals (76 males, 54 females) who were healty for their upper extremities and was seen in our orthopedics outpatient clinic during April 2019 to June 2019. The right and left clavicles and ulnas of each individual were measured. All measurements were peformed by two of the authors in an blinded fashion.

Results. Mean overall age was 32.2 years. There were significant correlations between the clavicle and ipsilateral ulnar lengths $(\mathrm{p}=0.001)$. However, there was a length difference between the right and left clavicles The left clavicle was $9.00 \pm 2.16 \mathrm{~mm}$ longer than the right in males and $7.13 \pm 2.03 \mathrm{~mm}$ longer in females $(\mathrm{p}=0.001)$. There was no significant length difference between the right and left ulnas in either sex $(0.84 \pm 1.033$ $\mathrm{mm}$ in males and $0.52 \pm 0.818 \mathrm{~mm}$ in females).

Conclusion. There is a significant ratio between the clavicle and ulna lengths on both the right and left sides in both sexes, but it isn't the same for males and females. We propose that these length proportion formula can be used for determining the clavicle length for the surgical treatment of comminuted fractures with plates and particularly with nails.
\end{abstract}

Key words: Comminuted fracture, clavicle, ulna, length ratio.

\section{Öz}

Amaç: Parçalı ve deplase kırıkların cerrahi rekonstrüksiyonu sırasında opere edilen kemiğin uygun boyunun tahmin edilebilmesi için bu kemik boyu ile komşu diğer bir kemiğin matematiksel olarak boy oranının kullanılması oldukça kullanışlıdır. Bu çalışmada parçalı klavikula kırıkları cerrahi tedavisi sırasında kullanılmak üzere, klavikula ve ulna kemikleri arasında matematiksel olarak anlamlı bir boy oranı olup olmadığının araştırılması amaçlanmıştır.

Yöntemler: Nisan-Haziran 2019 dönemi içerisinde, ortopedi ve travmatoloji polikliniğimizde görülen üst ekstremiteleri sağlıklı 130 hasta (76 erkek, 54 kadın) çalışmaya dahil edildi. Bütün hastaların sağ ve sol ulna ve klavikulaları birbirinin ölçümlerine kör 2 yazar tarafından, aynı yöntemler kullanılarak ölçüldü.

Bulgular: Toplamda ortalama yaş 32.2 yıl idi. Aynı taraf ulna ve klavikula boyları arasında anlamlı bir oran olduğu saptandı $(\mathrm{p}=0.001)$. Aynı zamanda sağ ve sol klavikula boyları arasında anlamlı uzunluk farkı bulunduğu görüldü. Sol klavikula, erkeklerde $9.00 \pm 2.16 \mathrm{~mm}$ ve kadınlarda $7.13 \pm 2.03 \mathrm{~mm}$ sağ klavikuladan daha uzun idi $(\mathrm{p}=0.001)$. Ancak her iki grupta da sağ ve sol ulna boyları arasında anlamlı bir fark saptanmadı $(0.84 \pm 1.033 \mathrm{~mm}$ erkeklerde ve $0.52 \pm 0.818 \mathrm{~mm}$ kadınlarda).

Sonuçlar: Hem kadın, hem de erkeklerde her iki tarafta klavikula ve ulna kemikleri arasında matematiksel olarak anlamlı bir oran var olduğu ortaya kondu. Ancak bu oran her iki cinsiyet için farklı idi. Biz bu çalıșmanın sonucuna dayanarak, parçalı klavikula kırıklarının plak ve özellikle çivi ile cerrahi tedavisi sırasında, ortaya konan bu orantısal formüllerin uygun kemik boyunun hesaplanarak sağlanması için kullanılabileceğini düşünmekteyiz.

Anahtar kelimeler: Parçalı kırık, klavikula, ulna, boy oranı.

\author{
${ }^{1}$ Health Sciences University, Umraniye Training \\ and Research Hospital, Department of \\ Orthopaedics and Traumatology, Istanbul, \\ Turkey. \\ ${ }^{2}$ Istanbul Medeniyet University, Faculty of \\ Medicine, Goztepe Training and Research \\ Hospital, Department Of Orthopaedics and \\ Traumatology, Istanbul, Turkey. \\ ${ }^{3}$ Istanbul Gelisim University, Faculty of Health \\ Sciences, Orthopaedic surgeon. Istanbul, \\ Turkey.
}

Ethics Committee Approval: The study wass approved by the local ethical authority (2013KAEK-64-2019/0235).

Etik Kurul Onayı: Çalışma lokal etik komite tarafindan onaylanmıştır (2013-KAEK-642019/0235)

Conflict of Interest: No conflict of interest was declared by the authors.

Çıkar Çatışması: Yazarlar çıkar çatışması

bildirmemişlerdir.

Financial Disclosure: The authors declared that this study has received no financial support. Finansal Destek: Yazarlar bu çalışma için finansal destek almadıklarını beyan etmişlerdir.

Geliş Tarihi / Received: 30.05.2019

Kabul Tarihi / Accepted: 17.07.2019

Yayın Tarihi / Published: 01.08.2019

Sorumlu yazar / Corresponding author:

Mehmet Salih Söylemez

Adres/Address: Health Sciences University,

Umraniye Training and Research Hospital, Department of Orthopaedics and Traumatology, Elmalıkent Mahallesi Adem Yavuz Cad. No:1 Ümraniye, Istanbul, Turkey. e-posta: slhsylmz@gmail.com

Tel/Phone: +905377743669

Copyright $($ C ACEM 


\section{Introduction}

Mathematical relationships between bones lengths and volumes have been evaluated to improve our understanding of normal and disordered growth, stature estimation, and biomechanics [1]. This approach known as "process structualism" advocates exploring regularities in biology as, this regularities may be very important $[1,2]$. Dogan and Aydınlioglu et al. [3, 4] had found evidence of fixed proportions between the length and width of metacarpals and phalanges in the foot. Besides authors defined proportions between the length and width of metatarcarpals and phalanges of hand as well. Although this philosophical perspective is a known issue among anatomists and mathematicians, its clinical application in to surgeons' daily practice is very limited.

Reconstruction of the length of a broken bone is at the utmost importance as inappropriate reconstruction will eventually result in further deterioration of the biomechanics of the extremity [5]. Particularly bones with irregular structures like the clavicle are the most challenging bones that allows exact estimation of its lengths during surgery [6].

Intramedullary nailing of clavicle fractures is an alternative to plate fixation, but it is difficult to estimate the proper length when using intramedullary devices because the clavicle has a double curvature and lies horizontally [6, 7], especially in comminuted fractures.

From this point of view, this study examined whether there is a mathematical relationship between the clavicle and another bone that can facilitate surgery and which bone is the easiest to measure with less exposure to radiation. During surgical intervention for clavicle fractures, the upper extremities are the easiest to access. In addition, the anatomical prominences of the upper extremity bones facilitate their evaluation without need for an X-ray. However, the lack of anatomical prominences on the humerus and radius makes them unsuitable for exact measurements. Therefore, we hypothesised that; if a proportion between lengths of both clavicles and ulnas exists, this finding can be applied to the clinical practice to estimate the length of the clavicle during a fracture surgery of this bone.

\section{Material and methods}

Study was conducted in accordance with principles for human experimentation as defined in the Declaration of Helsinki and approval was obtained from the institutional ethics committee and informed consent was received from all individuals. (Istanbul Medeniyet University, Goztepe Training and Research Hospital, Clinical Researchs Ethics Committee, Approval number: 2013-KAEK-64-2019/0235).

Study was carried out in our institution between April 2019 and June 2019. Individuals were examined only one time and further evaluation of measurements were not performed. The study enrolled 130 individuals (76 males, 54 females; mean age 32.2 years overall, 34.0 years for males, and 29.7 years for females) who were seen in our orthopedics outpatient clinic.

To increase the homogenity of the study only individuals from Caucasian races were included. Also individuls that had reached skeletal maturity and were healty for their upper extremities were included to the study. Individuals from other races rather than Caucasians, with recent trauma, a history of surgery, or congenital deformity of the upper extremities were excluded from the study.

The right and left clavicles and ulnas of each individual were measured while the individuals were standing, with both arms at their sides and their palms facing forward. The anatomical measurement points for the clavicle were the distal (lateral)-most prominence of the acromioclavicular junction and the medial-most prominence of the sternoclavicular joint (from the medial side of the sternal head of the sternocleidomastoid muscle) (Figure 1a). The measurement points for the ulna were the proximal-most prominence on the olecranon and the distalmost prominence on the ulnar styloid (Figure 1b).

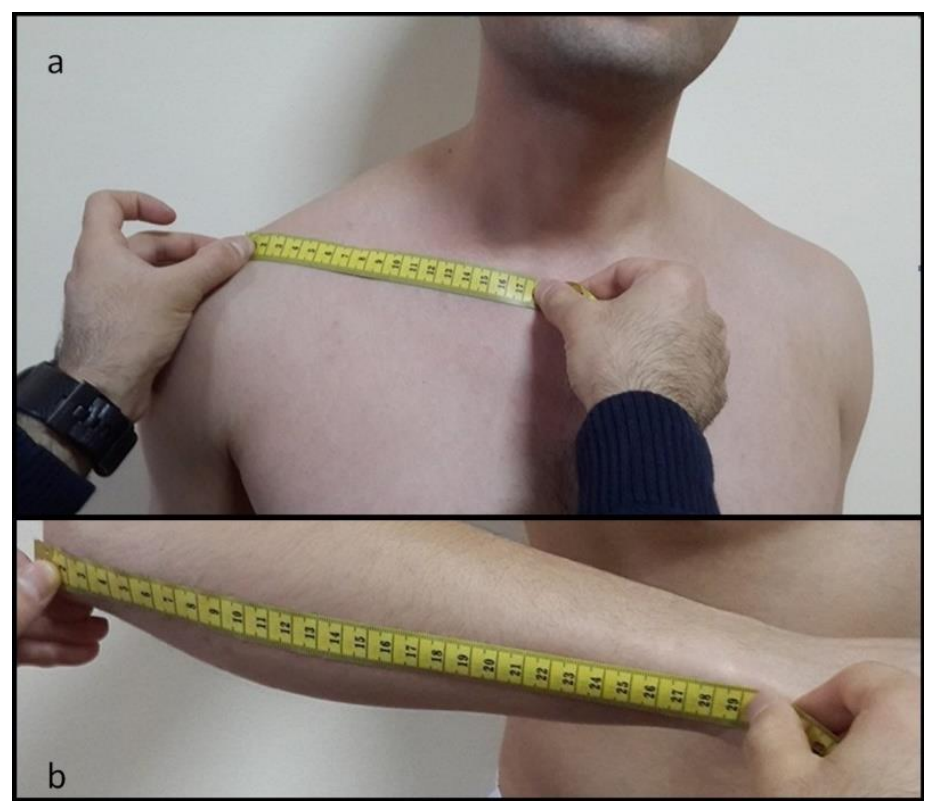

Figure 1. a) Measurement of clavicular length, b) measurement of ulnar length.

The measurements were made by two of the authors (M.D. and D.A.) in two different rooms. Each individual was evaluated by both surgeons, and each surgeon kept his records blind to the other. At the end of the study, all measurements were assessed by the senior author (K.O.) and the mean between the measurements was taken into account. After completion of clinical data collection, all measurements were analysed to find the mathematical relations between clavicula and ulna lengths and their difference among sexes.

Statistical analysis

Descriptive analysis was performed using SPSS ${ }^{\circledR}$ ver. 22.0 (IBM, Armonk, NY, USA). The Lilliefors-corrected Kolmogorov-Smirnov test was used to examine the normality of the distributions. The Levine test was used to examine the homogeneity of the variances. Independent samples t-tests with bootstrap results were used to compare two independent groups. A $p$ value of $<0.05$ was considered to be statistically significant for all analyses.

\section{Results}

There were significant correlations between the lengths of each clavicle and the ipsilateral ulna $(\mathrm{p}=0.001)$. In addition, there was a length difference between the right and left clavicles, with the left clavicle being $9.00 \pm 2.160$ millimeters $(\mathrm{mm})$ (range $12.00-5.00 \mathrm{~mm}$ ) longer than the right clavicle in males and 7.13 $\pm 2.029 \mathrm{~mm}$ (range 10.00-4.00 mm) longer in females ( $\mathrm{p}=$ 0.001). There was no significant length difference between the right and left ulnas in either sex $(0.84 \pm 1.033 \mathrm{~mm}$ in males and $0.52 \pm 0.818 \mathrm{~mm}$ in females, respectively). The data analyses showed small differences between the various ratios for males and females and the results are shown in Table 1.

The difference between sexes for the left clavicle/left ulna ratio was significant $(\mathrm{p}=0.046)$, while the differences for the clavicle/clavicle ratio $(\mathrm{p}=0.100)$ and right clavicle/right ulna 
( $\mathrm{p}=0.121$ ) were not significant. Therefore, although the left clavicle length can be determine in each sex with different ratio, the right clavicle length can be determined with the same ratio in both sexes (Figure 2).

Table 1: Ratios for males and females.

For Males

\begin{tabular}{ll} 
Right clavicle length/ipsilateral ulna length & $0.57 \pm 0.029 \mathrm{~mm}$ \\
Left clavicle length/ipsilateral ulna length & $0.60 \pm 0.028 \mathrm{~mm}$ \\
Right clavicle length/left clavicle length & $0.95 \pm 0.015 \mathrm{~mm}$ \\
For Females & \\
\hline Right clavicle length/ipsilateral ulna length & $0.56 \pm 0.029 \mathrm{~mm}$ \\
Left clavicle length/ipsilateral ulna length & $0.59 \pm 0.028 \mathrm{~mm}$ \\
Right clavicle length/left clavicle length & $0.95 \pm 0.015 \mathrm{~mm}$ \\
\hline
\end{tabular}

Figure 2. Data for right clavicle/right ulna, left clavicle/left ulna, and right clavicle/left clavicle ratios for both sexes.

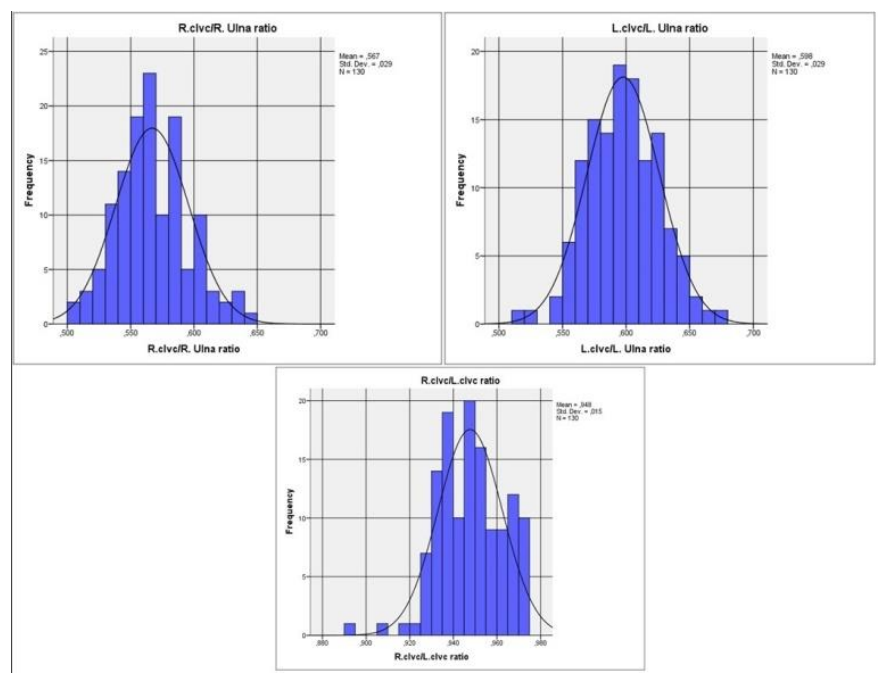

both sexes

Right clavicle length/ipsilateral ulna length $=0.57$ for

Right clavicle length/left clavicle length $=0.95$ for both

sexes

Left clavicle length/ipsilateral ulna length $=0.60$ for

males

females

Left clavicle length/ipsilateral ulna length $=0.59$ for in Table 2.

The results of the other measurements are summarized

Table 2. Descriptive analyses of the data.

\begin{tabular}{|c|c|c|c|c|}
\hline & $\frac{\text { Total }}{(\mathrm{N}=130)}$ & $\begin{array}{l}\text { Female } \\
(n=54)\end{array}$ & $\begin{array}{c}\text { Male } \\
(n=76)\end{array}$ & $\mathrm{P}$ \\
\hline Age $(\text { year })^{*}$ & $32.22 \pm 14.022$ & $29.70 \pm 13.198$ & $34.01 \pm 14.397$ & 0.081 \\
\hline $\begin{array}{l}\text { Right clavicle } \\
(\mathrm{mm})^{*}\end{array}$ & $152.05 \pm 12.032$ & $141.33 \pm 7.922$ & $159.67 \pm 7.944$ & 0.001 \\
\hline $\begin{array}{l}\text { Left clavicle } \\
(\mathrm{mm})^{*}\end{array}$ & $160.45 \pm 12.549$ & $148.72 \pm 8.013$ & $168.78 \pm 7.499$ & 0.001 \\
\hline $\begin{array}{l}\text { Length difference } \\
(\mathrm{mm})^{*}\end{array}$ & $8.22 \pm 2.293$ & $7.13 \pm 2.029$ & $9.00 \pm 2.160$ & 0.001 \\
\hline Right ulna $(\mathrm{mm})^{*}$ & $268.38 \pm 19.601$ & $251.54 \pm 11.955$ & $280.36 \pm 14.500$ & 0.001 \\
\hline Left ulna $(\mathrm{mm})^{*}$ & $268.64 \pm 19.719$ & $251.52 \pm 11.905$ & $280.80 \pm 14.411$ & 0.001 \\
\hline $\begin{array}{l}\text { Length } \\
\text { difference }(\mathrm{mm})^{*}\end{array}$ & $0.71 \pm 0.960$ & $0.52 \pm 0.818$ & $0.84 \pm 1.033 /$ & 0.133 \\
\hline $\begin{array}{l}\text { Right } \\
\text { clavicle/right } \\
\text { ulna }\end{array}$ & $0.57 \pm 0.029$ & $0.56 \pm 0.029$ & $0.57 \pm 0.029$ & 0.121 \\
\hline $\begin{array}{l}\text { Left clavicle/left } \\
\text { ulna }\end{array}$ & $0.60 \pm 0.029$ & $0.59 \pm 0.028$ & $0.60 \pm 0.028$ & 0.046 \\
\hline $\begin{array}{l}\text { Right clavicle/left } \\
\text { clavicle }\end{array}$ & $0.95 \pm 0.015$ & $0.95 \pm 0.015$ & $0.95 \pm 0.015$ & 0.100 \\
\hline
\end{tabular}

: : Mean \pm standard deviation.

\section{Discussion}

The anthropometric relations between the clavicle and the ulna is an unknown issue and there are very limited studies focusing on this issue $[1,2,5]$. Our study revealed that there are fixed proportions between ulna and the clavicle lengths. However these proportions are different among genders. These results can be applied to the clinical practice particularly during surgical intervention of comminuted the clavicle fractures.

The treatment of clavicle fractures remains controversial. Improvements in orthopedic surgery with new implant technologies have favored surgical intervention for midshaft clavicle fractures with improved clinical outcomes and earlier return to daily living activities. Surgery also reduces the nonunion and symptomatic malunion rates significantly compared with non-operative treatment, although the results still need to be improved [7,8].

Osteosynthesis with plates for the treatment of midshaft clavicle fractures has been used extensively and is still the gold standard surgical treatment for these fractures [9]. Nevertheless, osteosynthesis with plates has disadvantages like cosmesisrelated complaints due to the long incision scar, and delayed union or nonunion caused by excessive periosteal stripping in some cases [10]. Intramedullary nailing is being used successfully to treat fractures of this anatomically complex bone [11] because an intramedullary nail can be inserted with a minimally invasive technique. Closed reduction of the fracture preserves the fracture hematoma and the minimally invasive technique allows the surgeon to minimize soft-tissue dissection, thereby reducing surgical trauma, blood loss, infection, and wound complications [12]. Hill et al. [7] showed that the only parameter that affects fracture healing negatively in patients with a mid-shaft clavicle fracture is shortening exceeding $20 \mathrm{~mm}$. Neither comminution of the fracture nor treatment method affects the development of nonunion when the pre-fracture bone length is achieved and maintained. Despite its superiority over plates, the disadvantage of intramedullary fixation of improper assessment of length caused by the complex anatomy of the clavicle is a major concern [13].

Intramedullary devices behave as internal splints that maintain alignment without rigid fixation [12]. In a study comparing conservative treatment and intramedullary fixation of displaced non-comminuted fractures, Smekal et al. [14] showed that clavicle shortening was significantly less with intramedullary fixation. However, 2 years later in a different study comparing plate and intramedullary fixation of clavicle fractures, the same authors recommended intramedullary fixation only for non-comminuted fractures because of shortening [15]. With rapid improvements in nail design, we will soon overcome this problem and intramedullary fixation can be used even in comminuted fractures. Then, only the intraoperative assessment of clavicle length will be a matter of concern. Using only fluoroscopic imaging will be problematic because the double curved anatomy of the clavicle cannot be assessed exactly in two-dimensional (2D) images.

Several studies have helped to increase our understanding of the restoration of clavicle fractures with plates and intramedullary nails. According to Cunningham et al. [16] Their trial showed only $28 \%$ clavicle have more than $5 \mathrm{~mm}$ assymetry. Sehrawat et al. [17] found that left clavicle were longer length as our trial. Huang et al. [18] used a 3D digitizer to analyze the anatomy of the clavicle and applicability of precontoured clavicle plates. Bachoura et al. [19] found a positive correlation between the length of the clavicle, midpoint cortical diameter, and radius of the medial curvature of the clavicle. In a different study, the same authors tested the applicability of 
intramedullary nails for midshaft fracture fixation using a similar method [6]. Daruwalla et al. [20,.21] determined the complex anatomy of the clavicle using 3D computed tomography (CT) and performed principal components analysis of the clavicle. They found some variation in the shapes and sizes of the left and right clavicles between genders. Although this information can be used to design new nails or plates for clavicle fracture treatment, its clinical application may be impossible since obtaining 3D CT images for every patient exposes patients to unnecessary radiation and its use in clinical practice may not be cost-effective. However, the ulna and contralateral clavicle lengths can be measured easily and the optimal clavicle length can be calculated with the use of our proposed ratio, even during surgery.

Preoperative measurement of the contralateral clavicle seems to be more valuable than intraoperative measurement of the ipsilateral ulna. Although the lengths of the right and left clavicles differed in both sexes, this did not change the ratio between the right and left clavicles in either sex, and it is easier to keep this length differences in mind. When preoperative measurements have not been made, intraoperative ulna measurements can provide the same results.

This study had some limitations. First, it would have been better if more individuals had been measured. Second, this study examined only Caucasians, and the measurements may vary with race. We recommend keeping this information in mind before employing the technique. It may also be useful to perform the same study in different races.

In conclusion, we found different right and left clavicle/ulna ratios. There was a significant relationship between the right and left clavicles in both sexes, and it was the same for males and females. We propose that the proportions between the clavicle and ulna lengths can be used to determine the appropriate length of the clavicle during surgical fixation of comminuted fractures with plates and particularly nails. This study may also form a basis for future studies.

\section{References}

1. Pietak A, Ma S, Beck CW, Stringer MD. Fundamental ratios and logarithmic periodicity in human limb bones. J Anat. 2013;222:526-37.

2. Resnick D. The rebirth of rational morphology: process structuralism's philosophy of biology. Acta Biotheor. 1994;42:1-14.

3. Aydinlioglu A, Akpinar F, Tosun N. Mathematical relations between the lengths of the metacarpal bones and phalanges: surgical significance. Tohoku J Exp Med. 1998;185:209-16.

4. Dogan A, Uslu M, Aydinlioglu A, Harman M, Akpinar F. Morphometric study of the human metatarsals and phalanges. Clin Anat. 2007;20:209-14.

5. Hillen RJ, Bolsterlee B, Veeger DHEJ. The biomechanical effect of clavicular shortening on shoulder muscle function, a simulation study. Clin Biomech (Bristol, Avon). 2016;37:141-6.

6. Bachoura A, Deane AS, Kamineni S. Clavicle anatomy and the applicabil-ity of intramedullary midshaft fracture fixation. J Shoulder Elbow Surg. 2012;21:1384-90.

7. Hill JM, McGuire MH, Crosby LA. Closed treatment of displaced middle-third fractures of the clavicle gives poor results. J Bone Joint Surg Br. 1997;79:537-9.

8. Zlowodzki M, Zelle BA, Cole PA, Jeray K, McKee MD. Evidencebased Orthopaedic Trauma Working Group. Treatment of acute midshaft clavicle fractures: systematic review of 2144 fractures: on behalf of the Evidence-Based Orthopaedic Trauma Working Group. J Orthop Trauma. 2005;9:504-7.

9. McKee MD. Clavicle fractures in 2010: sling/swathe or open reduction and internal fixation? Orthop Clin North Am. 2010; 41:225-31.

10. VanBeek C, Boselli KJ, Cadet ER, Ahmad CS, Levine WN Precontoured plating of clavicle fractures: decreased hardware-related complications? Clin Orthop Relat Res. 2011;469:3337-43.

11. Wang XH, Cheng L, Guo WJ, Li AB, Cheng GJ, Lei T, et al. Plate Versus Intramedullary Fixation Care of Displaced Midshaft Clavicular Fractures: A Meta-Analysis of Prospective Randomized Controlled Trials. Medicine (Baltimore). 2015;94:e1792.
12. Kadakia AP, Rambani R, Qamar F, McCoy S, Koch L, Venkateswaran B. Titanium elastic stable intramedullary nailing of displaced midshaft clavicle fractures: A review of 38 cases. Int J Shoulder Surg. 2012;6:825 .

13. Chung HJ, Hong KJ, Kim DS. Biomechanical properties of titanium elastic nail applied toa cadaveric clavicle model. Orthop Traumatol Surg Res. 2015;101:823-6.

14. Smekal V, Irenberger A, Struve P, Wambacher M, Krappinger D, Kralinger FS. Elastic stable intramedullary nailing versus nonoperative treatment of displaced midshaft clavicular fractures-a randomized, controlled, clinical trial. J Orthop Trauma. 2009;23:106-12.

15. Smekal V, Irenberger A, Attal RE, Oberladstaetter J, Krappinger D, Kralinger F. Elastic stable intramedullary nailing is best for mid-shaft clavicular fractures without comminution: results in 60 patients. Injury. 2011;42:324-9

16. Cunningham BP, McLaren A, Richardson M, McLemore R. Clavicular length: the assumption of symmetry. Orthopedics. 2013;36:343-7.

17. Sehrawat JS, Pathak RK. Variability in anatomical features of human clavicle: Its forensic anthropological and clinical significance. Translational Res Anat. 2016;3:5-14.

18. Huang JI, Toogood P, Chen MR, Wilber JH, Cooperman DR. Clavicular anatomy and the applicability of precontoured plates. J Bone Joint Surg Am. 2007;89:2260-5.

19. Bachoura A, Deane AS, Wise JN, Kamineni S. Clavicle morphometry revisited: a 3 dimensional study with relevance to operative fixation. J Shoulder Elbow Surg. 2013;22:e15-21.

20. Daruwalla ZJ, Courtis P, Fitzpatrick C, Fitzpatrick D, Mullett H. Anatomic variation of the clavicle: A novel three-dimensional study. Clin Anat. 2010;23:199-209.

21. Daruwalla ZJ, Courtis P, Fitzpatrick C, Fitzpatrick D, Mullett H. An application of principal component analysis to the clavicle and clavicle fixation devices. J Orthop Surg Res. 2010;5:21. 